Program for Promoting Social Science Research

Aimed at Solutions of Near-Future Problems

Design of Interfirm Network to Achieve Sustainable Economic Growth Working Paper Series No.21

\title{
Determinants of business and financial network formation by Japanese start-up firms: Does founder's human capital matter?
}

\author{
Hiroyuki Okamuro \\ and \\ Kenta Ikeuchi
}

This version : March 27, 2013

Research Center for Interfirm Network

Institute of Economic Research, Hitotsubashi University

Naka 2-1, Kunitachi-city, Tokyo 186-8603, JAPAN

Tel: +81-42-580-9145

E-mail: hit-tdb-sec@ier.hit-u.ac.jp

http://www.ier.hit-u.ac.jp/ifn/ 


\title{
Determinants of business and financial network formation by Japanese start-up firms: Does founder's human capital matter?
}

\author{
Hiroyuki Okamuro (Hitotsubashi University) \\ and \\ Kenta Ikeuchi (National Institute of Science and Technology Policy)
}

\begin{abstract}
:
Business start-ups are expected to make major contributions to economic growth. However, most of them lack internal business resources that are necessary for survival and growth. Therefore, business and financial networks that provide business opportunity and external resources are essential for the post-entry performance of start-ups. However, previous studies have not explicitly investigated the determinants of network formation. We argue that the formation of business and financial networks by start-up firms depends on founder's human capital measured by university education and work experience, and empirically test it with our original survey data of recent Japanese start-ups. Moreover, we focus not only on the size of such networks, but also their quality measured as the status of major partners. Empirical results show that founder's industry experience for 10 or more years has positive and significant effect on the size of both business and financial networks, while founder's university education positively affects not only the size, but also the quality of both business and financial networks. Moreover, we also find that founder's specific strength and personality also significantly affect network formation. We find no distinct differences between the determinants of business and financial network.
\end{abstract}

Keywords: business network, financial network, start-up, founder, human capital JEL Classification Codes: L25, L26, M13 


\section{Introduction}

Business start-ups are expected to increase competition and contribute to innovation and economic growth (Audretsch et al., 2006). However, most start-ups are vulnerable to failures for the lack of internal business resources. It is only a small portion of start-up firms that really contribute to innovation and economic growth (Story, 1994a).

The firm is a pool of various tangible and intangible business resources. Both the quantity and quality of these resources determine the firm's capability and strongly affect the firm's post-entry performance, including survival and growth (Penrose, 1959). Elfring and Hulsink (2003) argue that entrepreneurial networks support high-tech start-ups in the early stage to discover opportunities, secure resources, and obtain legitimacy, which is important for their survival and performance. Similarly, we assume that transaction networks with business partners and financial institutions not only provide start-up firms with access to external business resources, but also signal their trustworthiness to a third party. Therefore, for small start-up firms with limited internal resources, networks with external organizations are essential for their survival and growth. Several studies demonstrate that entrepreneurial networks contribute to start-up performance. For example, Brüderl and Preisendörfer (1998) confirm positive network effects for survival and growth of new firms in Germany.

Founders of new firms often have to build up and develop such networks, which is, however, by no means an easy task. In fact, a recent survey by the Small and Medium Enterprise Agency in Japan reveals that, for the founders of start-up firms, exploitation of business partners is, together with raising funds, among the most serious difficulties at the early stage (Small and Medium Enterprise Agency, 2002): 34\% of the respondents report that they had difficulty in exploiting customers, while $49 \%$ had problem of insufficient internal funds and 33\% had difficulty in start-up finance.

Despite such importance, to the best of our knowledge, few empirical studies have been carried out on the formation of business and financial networks by start-up firms. Previous studies on start-up firms regard their network with external organizations as given. In this respect, we argue that founders' human capital plays an important role in establishing business and financial networks of start-up firms. Thus, the objective of this paper is to empirically explore the determinants of early network formation by start-up firms, with special attention to founder's characteristics.

As mentioned above, exploitation of business partners and obtaining external funds are both important issues for start-up firms, but they have been addressed in different fields of literature: marketing and finance. We assume that they are both affected by the characteristics 
of the founders of start-up firms, but their determinants may be partly different. Therefore, we separately estimate the determinants of business networks with customer firms and financial networks with banks, and compare the results of these estimations. Moreover, we also pay attention to the quality of networks, measured as the status of major partners.

The remainder of this paper is organized as follows. In the next section, we provide a brief overview of previous literature to demonstrate major contributions of this paper. In Section 3, we present conceptual framework and hypotheses. In Section 4, we explain empirical strategy including models and variables for estimation as well as our data and sample. In Section 5, we show estimation results and discuss these results. Section 6 concludes this paper.

\section{Previous literature}

Since the seminal work by Birley (1985), which explored the roles of founder's formal (banks, accountants, lawyers, and public agency) and informal (family, friends, and business contacts) networks, numerous studies have been conducted on the effects of entrepreneurial networks on firm performance (Cromie and Birley, 1992; Ostgaard and Birley, 1996; Hansen, 1995; Brüderl and Preisendörfer, 1998; Chell and Baines, 2000; Witt, 2004). Also with regard to nascent entrepreneurs, Davidsson and Honig (2003) find that a membership of business networks, such as the Chamber of Commerce, Rotary or Lions Club has a positive effect on their business performance by following their activities for 18 months. Further, Lechner et al. (2006) argue that the "relational mix" of different types of networks is a more important factor for explaining firm development than sheer network size, and demonstrate that the "reputational" network with highly regarded firms or individuals plays an important role at the early stage.

However, these studies do not explicitly investigate the determinants of network formation. Moreover, they mostly focus on social and personal ties of founders or their relationship with providers of professional services such as lawyers, accountants, and business consultants, without explicitly considering the relationships with business partners and banks, or distinguishing them from the founders' social and personal ties.

With regard to firms' networks, several empirical studies have been conducted on the determinants of research collaborations with other firms (including business partners) or research institutes, but, with the exceptions of Colombo et al. (2006) for Italy and Okamuro et al. (2011) for Japan, few studies have focused on start-up firms and on the role of founder's human capital in establishing such networks. Moreover, as far as we know, no studies have explicitly addressed the determinants of business networks with customers or suppliers, 
although, as mentioned before, networks with business partners may strongly affect start-up performance.

There are numerous studies on financing of small businesses and start-ups. Several studies suggest that financial constraints significantly affect start-up decisions (Evans and Jovanovic, 1989) and post-entry performance (Holtz-Eakin et al., 1994; Becchetti and Trovato, 2002) because access to external funding such as bank loans is limited for start-up firms in imperfect capital market. Therefore, it is essential for the post-entry performance of start-up firms to establish transaction networks with banks.

Some studies have empirically investigated the effects of founder's human capital on the external funding, especially on bank borrowing, of start-up firms, with quite different results. Bates (1990) and Storey (1994b) show that founders with higher education are more likely to use bank borrowings. On the contrary, Astebro and Bernhardt (2003) find that business owners with higher education and rich business experience have lower propensity to depend on bank loans when they started new businesses. Moreover, Cassar (2004) finds with a sample of new businesses from a national survey in Australia that owner's characteristics including gender, education, and industry experience have no effects on external financing, nor bank loans.

However, to the best of our knowledge, no studies have explicitly investigated the effects of founder's human capital on the structure of financial networks, considering the number and the status of banks with which they have financial transactions. The number of trading banks matters for start-up firms because it relates to the amount of available bank loans and also to the bargaining power of start-up firms in financial transactions. Moreover, following the argument by Lechner et al. (2006), we may assume that also the reputation or status of trading banks is important.

Therefore, this paper aims at filling this gap by empirically estimating the effects of founder's human capital on the formation of both business and financial networks of start-up firms. Moreover, we will consider not only network size, but also network quality or the reputation of network members that may be measured by the "status" of major business partners and banks.

\section{Conceptual framework and hypotheses}

Our basic idea is that founder's human capital, including his or her education and business experience, is often the most important resource for small start-up firms. Referring to Fontana et al. (2006) and Okamuro et al. (2011), we argue that founder's higher (university) education 
and business experience represent their ability and personal network (in size and quality), and signals their ability to a third party, say, potential business partners or lenders of bank loans ${ }^{1}$. Therefore, we consider the founders with higher education and longer business experience to have larger business and financial networks than others.

Here, we assume that larger network is better for start-up firms because larger network brings more external resources and thus more opportunity to them and the start-ups are less dependent on a specific partner in a larger network, which makes them more vulnerable to exploitation. It may not always be an optimal strategy for start-ups to have as many customers as possible. Rather, some firms may prefer concentrating on a few good customers to transacting with many. However, our sample firms have on average less than 5 customers only, whereas several start-up firms find it difficult to exploit their customers, as we presented earlier. Moreover, start-ups tend to be vulnerable to external shocks because of limited business resources and experience, and increase their customers than depend on a few ones. Therefore, we argue that it would be important for most start-up firms to increase the number of business partners

Previous studies focus either on business or financial networks. We assume that both networks can be affected by founders' human capital, but the determinants may differ between them. Therefore, we compare the determinants of business and financial networks by estimating them separately with the same sample.

Based on these arguments, we propose the following hypotheses regarding network size.

H1a: Founders with university education tend to establish larger business network than those without university education.

H1b: Founders with university education tend to establish larger financial network than those without university education.

H2a: Founders with longer business experience tend to establish larger business network than those with shorter business experience.

H2b: Founders with longer business experience tend to establish larger financial network than those with shorter business experience.

Not only the network size may be important for start-up firms. Both business partners (customer firms) and financial institutions are heterogeneous. For example, it may be more prestigious and thus more difficult for start-up firms to become suppliers for large and

\footnotetext{
${ }^{1}$ Also Bates (1990) and Story (1994b) argue that founders' education and experience may provide signals of better human capital and thus the greater viability of start-ups, enabling them better access to bank loans.
} 
established firms than small, unknown customers. Similarly, it may be more prestigious and thus more difficult for start-up firms to be financed by the largest banks ("city banks") than by smaller, regional banks or credit associations ${ }^{2}$, because traditionally city banks have concentrated on lending to large and established corporations. Indeed, as shown later, only 9\% of our sample firms borrow from a city bank. Therefore, transactions with large and established customer firms and banks, especially city banks, may indicate high quality network of start-up firms. Lechner et al. (2006) suggest that reputational networks with highly regarded firms play an important role for firms' development especially at the start-up stage by signaling their credibility.

In the following part, we regard large and established customers as superior customers and city banks as superior banks, respectively. In the same line, we regard business networks with superior customers as superior business network and financial networks with superior banks as superior financial network, respectively, and distinguish them from other business or financial networks. Based on the above argument, we consider superior networks to be more beneficial for start-up firms than others. Hence, we add following hypotheses regarding the formation of superior networks.

H3a: Founders with university education tend to establish superior business network than those without university education.

H3b: Founders with university education tend to establish superior financial network than those without university education.

H4a: Founders with longer business experience tend to establish superior business network than those with shorter business experience.

H4b: Founders with longer business experience tend to establish superior financial network than those with shorter business experience.

Moreover, we assume that also the founder's evaluated strength in sales, technology, or accounting as well as their personality (active, steady, responsible, serious, sociable, inventive, etc.) affect network formation, and thus control for these characteristics in the estimation. For example, the founders who have distinct strength in sales may have it easier to find customers, while those with accounting expertise may give better impression to bankers than others.

\footnotetext{
${ }^{2}$ City banks can be defined here as the largest private banks in Japan that set up their branches in the whole country. Although there is no legal definition of city banks, usually the following four banking groups are regarded as city banks since 2006: the Bank of Tokyo-Mitsubishi UFJ (BTMU), Sumitomo Mitsui Banking Corporation (SMBC), Mizuho Bank (MHBK), and Resona Bank. The first three groups are also called mega banks.
} 
Network formation with business partners and banks may also depend on firm level characteristics, such as firm age, firm size, industry, and location. For example, it may be easier for larger firms with more track records to find superior customers and to get financed by superior banks. Therefore, we control for these variables in the estimation.

\section{Empirical methods}

In this section, we explain our data source, sample firms, and empirical models to estimate the determinants of the "size" and "quality" of business and financial network of new start-up firms.

The sample firms are obtained from the company database of Teikoku Data Bank (TDB), the largest and oldest credit research institute in Japan. The original database covers more than one million business corporations in Japan, most of which are small, unlisted firms. This database contains accounting data as well as detailed information on business transactions with other firms (business networks), financial relationship with banking institutions (financial network), and the firm's president. Thus, it contains all necessary information for our purpose. A distinct feature of this database is that it does not only provide the names of customer and supplier firms, but also their individual company codes, so that we may precisely identify them and collect their company data. The same applies to the lenders of bank loans. However, we cannot obtain information on informal networks including nonpecuniary transactions, political connections, and president's personal ties or social networks.

This database has been available to us since 2008, so that we may construct panel dataset of numerous firms for a couple of years. However, for this paper we use a cross-section sample of most recent available data because information on start-up firms is not necessarily under annual updates. The dates of investigations by TDB range from December 2007 to March 2010. It is noteworthy that we do not necessarily have and use the data on firms when they were founded, but the most recent available data. Such data constraints may induce endogeneity or simultaneity problems, but we use firm level variables just to control for the effects of main variables for founder's human capital.

From this database, we derived new and independent firms that belong to manufacturing, wholesale, and business service sectors, because we focus on business networks of independent firms at the start-up stage with customer firms. Thus, our sample consists of the corporations within three years since start-up that were founded and owned by the current president and excludes the firms in the sectors of consumer services. Our final sample 
comprises 4,847 firms for the analysis of business network and 6,582 firms for the analysis of financial network.

We have two groups of dependent variables: proxies for network size and quality. We define the size of business and financial networks as the numbers of customer firms and banks with lending relationship, respectively. The quality of business and financial networks is measured by the number of customer firms listed on the stock exchange and the availability of loans from city banks, respectively. Thus, we have four dependent variables for the empirical estimation, among which two represent business networks (size and quality) and another two represent financial networks (size and quality).

Table 1 shows the descriptive statistics of the sample firms. Regarding business networks, the average number of customer firms is 4.7 (the maximum is 35). Among the customer firms, we find on average one company listed on the stock exchange (20 at a maximum). Regarding financial networks, the number of lenders of bank loans is 0.47 on average (eight at a maximum), thus a half of the start-up firms obtain no bank loans. Moreover, only 9 percent of start-up firms borrow from a city bank ${ }^{3}$.

As the determinants of the network size and quality, we focus on two types of founders' human capital: education level and business experiences. As a proxy for the education level, we use a dummy variable of whether or not the founder of the firm has a university degree. In our sample, 40 percent of founders have a university degree. As the variables of business experiences, we use the length of founder's experience in the same industry (industry experience) and in the management of firms (managerial experience). Because these variables are available only in three categories (less than 3 years, 3 to 10 years, and 10 years or more, we include two dummy variables for the latter two categories. In our sample, 68 percent of founders have relatively long (10 years or more) industry experience, while founders with managerial experience for 10 years or more are limited to $16 \%$. It is noteworthy that we focus on the president as the founder of start-up firms for the lack of information on co-founders ${ }^{4}$.

We also include several control variables. First, we control for the effects of firm characteristics including firm age, firm size, sector and location on the network formation. Firm age is limited to three years for our sample. Firm size is measured by the number of

\footnotetext{
${ }^{3} 20 \%$ of the sample firms obtain loans from private banks. This suggests that most start-up firms do not obtain loans from private banks (although several firms may obtain loans from public banks) and that a half of the start-up firms that obtain loan from private banks obtain it from city banks.

${ }^{4}$ Several firms may be founded by more than one persons and thus have co-founders. Recent studies pay attention to the roles of co-founders. However, our database does not provide any information on co-founders. We can only know whether or not the current president is the founder, but cannot know who among the directors are co-founders or latecomers.
} 
employees in natural logarithm. Sample firms have on average 6.4 employees. As the variables for sectors, we use sector dummies for wholesale (46\%) and business services (38\%), taking manufacturing (16\%) as the baseline reference. As location variable, we use a dummy variable for metropolitan areas that takes on the value one if the firm is located in Tokyo or Osaka, and zero otherwise. A half (53\%) of the sample firms are located in these metropolitan areas. It is noteworthy that, as mentioned before, we do not have the data of the firms when they were founded, but the most recent available data.

Second, other founder characteristics are also controlled for, including age, gender, forte in business, and personality. Founders of sample firms are on average 46 years old at start-up. Female founders are only $6.5 \%$. We use the female founder dummy to control for any possible gender differences. Founder's forte in business is subjectively evaluated by the investigators of TDB, and based on their evaluations, we use dummy variables for being strong in sales (65\%), technology (29\%), accounting (2\%), and administration (24\%) ${ }^{5}$. Founder's personality is also evaluated by individual investigators of TDB as multiple choices. From among several items, we use only those that apply to at least $10 \%$ of the founders of sample firms: "serious" (47\%), "person who gets things done" (33\%), "active" (26\%), "steady" (24\%), "sociable" (19\%), “superior planning ability” (19\%), “wide personal network” (15\%), "responsible” (14\%), “visionary” (13\%), “technology-oriented” (11\%), and “careful” (11\%).

Founder's characteristics including human capital variables were not observed and documented at the time of starting up new business, but at the latest investigation by TDB. However, we can exactly identify in this database whether or not the president is the founder, and we focus on the firms in which the founder remained the president. Therefore, we regard the variables of founder's characteristics as exogenous, assuming that they are time-invariant at least after start-up.

We present correlation matrix of the dependent and independent variables in the Appendix. We find that the size of business and financial networks have a low coefficient of correlation (0.145), but the size and the quality of business networks are highly correlated (0.696), as well as the size and the quality of financial networks (0.531).

We employ negative binomial models to estimate the determinants of network formation, except for the quality of financial network, because the relevant dependent variables are count data $^{6}$. Regarding the quality of financial network, we use probit model to estimate the probability for a start-up firm to be financed by a city bank because only a small portion of

\footnotetext{
${ }^{5}$ This is a multiple-choice item, so that a founder may have no or more than one fortes.

${ }^{6}$ The results of over-dispersion tests suggest that we should employ negative binomial models rather than Poisson models.
} 
start-ups achieve it, and thus it is more important whether or not a start-up firm is financed by city banks rather than how many city banks finance it.

\section{Estimation results and discussion}

Table 2 presents the estimation results of four models with different dependent variables. Among our hypotheses, H1a and H2a correspond to Model 1, H3a and H4a correspond to Model 2, H1b and H2b correspond to Model 3, and H3b and H4b correspond to Model 4. We show estimated coefficients for Models 1, 2, and 3 (negative binomial models) and marginal effects for Model 4 (probit model). We first report the estimation results of each model on founder's characteristics, focusing on the human capital variables, and then explain the results on firm characteristics.

With regard to business network size (Model 1), we find that, among founder's human capital, university education and a long business experience (10 years or more) in the same industry have positive and significant effects on the number of customer firms. However, long experience in management (10 years or more) has rather negative and significant effect on business network size. These results support H1a and partially also H2a (with regard to industry experience). Moreover, from among founder's forte and personality, strength in sales, technology, and accounting as well as active, sociable, and serious personality positively affect the size of business network. Founder's age and gender have no effects on the size of business network.

Regarding the quality of business network (Model 2), measured by the number of listed customers, we obtain similar results, except that industry experience and strength in sales and accounting have no more significant effects. It is also similar to the results of Model 1 that the founder's long managerial experience has negative and significant effect. These results support H3a, but not H4a. Similar results to Model 1 can be expected also from a high correlation of the dependent variables (0.696) for Models 1 and 2.

Models 3 and 4 show the results on the size and quality of financial networks, respectively. Similar to the results on business network size (Model 1), we find positive and significant effects of university education and long industry experience, but negative and significant effect of long managerial experience, on the number of trading banks (Model 3). These results support $\mathrm{H} 1 \mathrm{~b}$ and partially also $\mathrm{H} 2 \mathrm{~b}$ (with regard to industry experience). It is also common to the estimation results of Model 1 that, among founder's characteristics, founder's strength in sales and accounting as well as active, sociable, and serious personality positively affect the 
size of financial network. Interestingly, female founders tend to rely on fewer banks, while gender of founders does not affect the other aspects of network formation.

Regarding the quality of financial network (Model 4), university education has positive and significant effect on the probability of borrowing from the largest private banks, while industry experience has no significant effects. Similar to the results of the other estimations, managerial experience is negatively correlated with the quality of financial network. These results support H3b but not H4b.

In sum, among our hypotheses, H1a, H1b, H3a, and H3b are supported, but H2a and H2b are only partially supported (with regard to industry experience but not managerial experience), and $\mathrm{H} 4 \mathrm{a}$ and $\mathrm{H} 4 \mathrm{~b}$ are not supported by the estimation results. In other words, among founder's human capital, university education has positive and significant effects on both the size and quality of business and financial networks, while long industry experience positively affect only the size of business and financial networks. Long managerial experience has rather negative and significant effects on the size and quality of both networks.

Unexpected negative impact of managerial experience on network formation by start-up firms may be explained by different strategies between the founders with and without experiences in management: Founders with managerial experience may know their customer firms and banks well and prefer concentrating their business and banking relationship on fewer, selected partners. However, such interpretation is not consistent with the results that the founders with managerial experience have also lower-quality networks: They have fewer listed customers and are less likely to borrow from the city banks. Another interpretation is that the founders with managerial experience include those who founded a new firm after a business failure. In such case, the managerial experience with business failures may provide negative signals to potential customers and banks. In general, it may be a weakness of this research that we cannot distinguish between intended and unintended results on network size and quality. That is, founders may select or be constrained to small numbers of customers or banks.

Founder's age has no effects on network formation except for the quality of business networks, even after controlling for the length of business experiences: Older founders tend to find more listed corporations as their customers. Moreover, female founders tend to have fewer trading banks, even after controlling for their human capital, but otherwise we find no significant differences in network formation between male and female founders.

With regard to firm characteristics, we find that, as expected, age and employee size of start-up firms are positively and significantly correlated with all dependent variables of business and financial networks. The estimation results also suggest that the size and quality 
of business and financial networks differ across sectors and location of start-up firms: The firms in the business services sector and in the metropolitan areas have larger and more qualified business networks, but have fewer trading banks, than those in the manufacturing sector and those in the other areas. Probability of being financed by the largest private banks is also higher in the metropolitan areas, but does not depend on business sectors ${ }^{7}$.

It is noteworthy that, as mentioned above, the variables for founder's characteristics can be regarded as exogenous because founder's age, gender, education level, business experiences, and personality are fixed before starting up new firms and so do not change nor affected by network formation after start-up. However, we cannot identify the causality between firm characteristics, such as age and size, and network formation because of data constraints.

As a whole, our empirical results are consistent with the findings of some previous studies on alliance formation in that founder's human capital signals the ability of start-up firms to potential partners (Fontana et al., 2006; Okamuro et al., 2011). On the contrary, with regard to bank relationship, our results differ from Cassar (2004) that find no effects of new business owner's characteristics on external funding and bank borrowing. Such difference may be attributed to the fact that we use a far larger sample and more variables than Cassar (2004).

\section{Concluding remarks}

Business start-ups increase competition and contribute to innovation and economic growth. However, opportunities for survival and growth are limited for most start-ups because of constraints of internal resources. Transaction networks with business partners and financial institutions can increase their opportunities for survival and growth by providing them access to external business resources. Moreover, reputation networks with highly regarded partners may signal the capability and trustworthiness of start-up firms to a third party, which again contributes to improving their performance.

Indeed, several studies demonstrate that entrepreneurial networks at the early stage contribute to start-up performance. However, to the best of our knowledge, few empirical studies have been carried out on the determinants of network formation by start-up firms. Thus, the purpose of this paper was to empirically investigate the determinants of transactions network formation by independent start-up firms in Japan, using micro data compiled by TDB.

\footnotetext{
${ }^{7}$ As robustness checks, we replaced these sector dummies with 2-digit industry dummies and the dummy for the location in metropolitan areas (Tokyo or Osaka) with prefecture dummies, and obtained similar results to those in Table 3 with regard to the effects of the other variables on network formation.
} 
Especially, we distinguished between networks with business partners (business networks) and those with financial institutions (financial networks).

We focused on founders' human capital such as education level and work experience as the determinants of network formation. Estimation results show that university education and a long experience in the same industry positively affect the size of both business and financial networks, while transactions with highly regarded partners (listed companies and city banks) are not supported by a long industry experience of the founders. Moreover, we found certain strength and personality of founders are significantly related to network formation. Finally, we found few major differences between the determinants of business and financial network formation.

Our study may suffer from some constraints of the database. First, there is a latent problem of sampling bias: The TDB database does not cover all start-up firms in Japan, but only a part of them. TDB usually inquires into the firms based on customers' requests. Assuming that the investigated firms came into consideration as business partners or recipients of bank loans, we cannot exclude the possibility that our estimation results may be upper-biased as compared to the population. Second, we used a cross-section sample of start-up firms within three years of operation for lack of panel dataset. In this sense, our analysis is static. It would be more interesting to analyze dynamic development of networks of start-up firms over time (Schutjens and Stam, 2003). Third, founders' strength and personality, which partly affect network formation, were measured by subjective evaluations of individual investigators. However, it would be difficult to obtain more objective measures on these characteristics of founders. Fourth and last, we do not have any detailed information on the transaction with each partner. Especially regarding banking relationship, information on the conditions of each financing including interest rate, length, and collateral is not available. However, positive effect of university education may be related with these conditions, such as the amount of personal asset that can be provided as collateral.

Despite these remaining problems, our findings may provide some managerial and policy implications. The founders of start-up firms and those who are preparing for starting up new business should be aware that the propensity to establish business and financial networks, which are keys to their success, might be constrained by their education level and business (industry) experience. They should also be aware that their observed strength and personality also play important roles in establishing business and financial networks. Policy makers who are involved in promoting start-up firms should support business and financial matching for those with lower level of founder's human capital, because the founders with higher education and rich business experience have less difficulty in network formation. 
Moreover, we may also provide some suggestions for future research on entrepreneurship: First, empirical studies on entrepreneurial network should regard it as depending on founder's human capital. Second, future research on entrepreneurial network should take founder's personality into consideration, because it significantly affects network formation and thus the success of start-up firms.

\section{Acknowledgments:}

The company database of Teikoku Data Bank was made available through the research project at Hitotsubashi University "Design of industry and financial network where sustained growth is enabled", financed by the Japan Society for the Promotion of Science. The authors appreciate this support. An early version of this paper was presented at the Conference on the Dynamics of Entrepreneurship (CoDE) at ZEW in Mannheim, Germany, in October 2013, and at the RENT XXVI Conference in Lyon, France, in November 2013. We thank the participants of these conferences for helpful comments. Any remaining errors and omissions are of our own responsibility. 


\section{References:}

Astebro, T. and Bernhardt, I. (2003), Start-up financing, owner characteristics, and survival. Journal of Economics and Business 55, 303-319.

Bates, T. (1990), Entrepreneur human capital inputs and small business longevity. Review of Economics and Statistics 72, 551-559.

Becchetti, L. and Trovato, G. (2002), The determinants of growth for small and medium sized firms. The role of the availability of external finance. Small Business Economics 19, 291306.

Birley, S. (1985), The role of networks in the entrepreneurial process. Journal of Business Venturing 1, 107-118.

Brüderl, J. and Preisendörfer, P. (1998), Network support and the success of newly founded firms. Small Business Economics 10, 213-225.

Cassar, G. (2004), The financing of business start-ups. Journal of Business Venturing 19, 261283.

Chell, E. and Baines, S. (2000), Networking, entrepreneurship and microbusiness behaviour. Entrepreneurship and Regional Development 12, 195- 215.

Colombo, M.G., Grilli, L., and Piva, E. (2006), In search of complementary assets: The determinants of alliance formation of high-tech start-ups. Research Policy 35, 1166-1199.

Cromie, S. and Birley, S. (1992), Networking by female business owners in Northern Ireland. Journal of Business Venturing 7, 237-251.

Davidsson, P. and Honig, B. (2003), The role of social and human capital among nascent entrepreneurs. Journal of Business Venturing 18, 301-330.

Elfring, T. and Hulsink, W. (2003), Networks in entrepreneurship: The case of hightechnology firms. Small Business Economics 21, 409-422.

Evans, D.S. and Jovanovic, B. (1989), An estimated model of entrepreneurial choice under liquidity constraints. Journal of Political Economy 97, 808-827.

Fontana, R., Geuna, A., and Matt, M. (2006), Factors affecting university-industry R\&D projects: The importance of searching, screening, and signaling. Research Policy 35, 309323.

Hansen, E.L. (1995), Entrepreneurial networks and new organization growth. Entrepreneurship Theory and Practice 19, 7-19.

Holtz-Eakin, D., Joulfaian, D., and Rosen, H.S. (1994), Sticking it out: entrepreneurial survival and liquidity constraints. Journal of Political Economy 102, 53-75.

Lechner, C., Dowling, M. and Welpe, I. (2006), Firm networks and firm development: The 
role of the relational mix. Journal of Business Venturing 21, 514-540.

Okamuro, H., Kato, M., and Honjo, Y. (2011), Determinants of R\&D cooperation in Japanese start-ups, Research Policy 40, 728-738.

Ostgaard, T.A. and Birley, S. (1996), New venture growth and personal networks, Journal of Business Research 36, 37-50.

Penrose, E.T. (1959), The Theory of the Growth of the Firm. London: Basil Blackwell.

Schutjens, V. and Stam, E. (2003), The evolution and nature of young firm networks: A longitudinal perspective. Small Business Economics 21, 115-134.

Storey, D. J. (1994), Understanding the Small Business Sector. London: Routledge.

Storey, D. J. (1994), The role of legal status in influencing bank financing and new firm growth, Applied Economics 26, 129-136.

Witt, P. (2004), Entrepreneurial networks and the success of start-ups. Entrepreneurship and Regional Development 16, 391-412. 
Table 1: Descriptive Statistics

\begin{tabular}{|c|c|c|c|c|c|}
\hline Variables & Obs. & Mean & Std. Dev. & Min & Max \\
\hline Number of customers & 5,228 & 4.706 & 3.522 & 1.0 & 35.0 \\
\hline Number of listed customers & 5,228 & 1.025 & 1.548 & 0.0 & 20.0 \\
\hline Number of lenders of bank loans & 7,638 & 0.469 & 0.758 & 0.0 & 8.0 \\
\hline Borrowing from "city banks" & 7,638 & 0.089 & 0.285 & 0.0 & 1.0 \\
\hline Firm age & 7,638 & 1.607 & 0.838 & 0.0 & 3.0 \\
\hline Number of employees & 7,638 & 6.434 & 22.082 & 0.0 & 645.0 \\
\hline log of number of employees & 7,638 & 1.289 & 1.062 & 0.0 & 6.5 \\
\hline Manufacturing sector dummy (reference) & 7,638 & 0.161 & 0.368 & 0.0 & 1.0 \\
\hline Wholesale sector dummy & 7,638 & 0.457 & 0.498 & 0.0 & 1.0 \\
\hline Business service sector dummy & 7,638 & 0.382 & 0.486 & 0.0 & 1.0 \\
\hline Location - Tokyo or Osaka & 7,359 & 0.530 & 0.499 & 0.0 & 1.0 \\
\hline Age at start-up & 6,935 & 46.291 & 11.045 & 19.9 & 92.4 \\
\hline Gender (female) dummy & 7,616 & 0.065 & 0.247 & 0.0 & 1.0 \\
\hline Education: University & 7,638 & 0.396 & 0.489 & 0.0 & 1.0 \\
\hline Education: Junior or technical college & 7,638 & 0.018 & 0.134 & 0.0 & 1.0 \\
\hline Industry experience: 3-10 years & 7,295 & 0.173 & 0.378 & 0.0 & 1.0 \\
\hline Industry experience: 10 or more years & 7,295 & 0.681 & 0.466 & 0.0 & 1.0 \\
\hline Managerial experience: 3-10 years & 7,444 & 0.152 & 0.359 & 0.0 & 1.0 \\
\hline Managerial experience: 10 or more years & 7,444 & 0.157 & 0.364 & 0.0 & 1.0 \\
\hline Strength in sales & 7,638 & 0.645 & 0.478 & 0.0 & 1.0 \\
\hline Strength in technology & 7,638 & 0.292 & 0.455 & 0.0 & 1.0 \\
\hline Strength in accounting & 7,638 & 0.025 & 0.156 & 0.0 & 1.0 \\
\hline Strength in administration & 7,638 & 0.204 & 0.403 & 0.0 & 1.0 \\
\hline Personality - careful & 7,638 & 0.105 & 0.307 & 0.0 & 1.0 \\
\hline Personality - active & 7,638 & 0.258 & 0.438 & 0.0 & 1.0 \\
\hline Personality - responsible & 7,638 & 0.136 & 0.343 & 0.0 & 1.0 \\
\hline Personality - technology-oriented & 7,638 & 0.108 & 0.311 & 0.0 & 1.0 \\
\hline Personality - steady & 7,638 & 0.240 & 0.427 & 0.0 & 1.0 \\
\hline Personality - visionary & 7,638 & 0.128 & 0.334 & 0.0 & 1.0 \\
\hline Personality - serious & 7,638 & 0.466 & 0.499 & 0.0 & 1.0 \\
\hline Personality - wide personal network & 7,638 & 0.152 & 0.359 & 0.0 & 1.0 \\
\hline Personality - person who gets things done & 7,638 & 0.330 & 0.470 & 0.0 & 1.0 \\
\hline Personality - sociable & 7,638 & 0.189 & 0.392 & 0.0 & 1.0 \\
\hline Personality - superior planning ability & 7,638 & 0.186 & 0.389 & 0.0 & 1.0 \\
\hline
\end{tabular}


Table 2: Estimation Results

\begin{tabular}{|c|c|c|c|c|c|c|c|c|c|c|c|c|}
\hline \multirow{3}{*}{$\begin{array}{l}\text { Models: } \\
\text { Dependent variables: } \\
\text { Estimation Methods: }\end{array}$} & \multicolumn{3}{|c|}{1} & \multicolumn{3}{|c|}{2} & \multicolumn{3}{|c|}{3} & \multicolumn{3}{|c|}{4} \\
\hline & \multicolumn{3}{|c|}{ Number of customers } & \multicolumn{3}{|c|}{$\begin{array}{l}\text { Number of listed } \\
\text { customers }\end{array}$} & \multicolumn{3}{|c|}{$\begin{array}{c}\text { Number of lenders of } \\
\text { bank loans }\end{array}$} & \multicolumn{3}{|c|}{$\begin{array}{l}\text { Borrowing from city } \\
\text { bank }\end{array}$} \\
\hline & \multicolumn{3}{|c|}{ Negative binomial } & \multicolumn{3}{|c|}{ Negative binomial } & \multicolumn{3}{|c|}{ Negative binomial } & \multicolumn{3}{|c|}{ Probit } \\
\hline \multicolumn{13}{|l|}{ (Firm characteristics) } \\
\hline Firm age & 0.087 & {$[0.012]$} & $* *$ & 0.104 & {$[0.025]$} & $* *$ & 0.419 & {$[0.023]$} & $* *$ & 0.037 & [0.004] & $* *$ \\
\hline log of number of employees & 0.146 & [0.009] & $* *$ & 0.283 & [0.019] & ** & 0.247 & [0.017] & $* *$ & 0.029 & {$[0.003]$} & $* *$ \\
\hline Wholesale sector dummy & 0.062 & {$[0.030]$} & $*$ & -0.085 & {$[0.063]$} & & 0.078 & {$[0.053]$} & & 0.004 & {$[0.010]$} & \\
\hline Business service sector dummy & 0.092 & {$[0.030]$} & $* *$ & 0.181 & {$[0.063]$} & $* *$ & -0.238 & {$[0.056]$} & $* *$ & -0.004 & {$[0.010]$} & \\
\hline Location - Tokyo or Osaka & 0.080 & {$[0.021]$} & $* *$ & 0.373 & {$[0.044]$} & $* *$ & -0.163 & [0.038] & $* *$ & 0.093 & [0.007] & $* *$ \\
\hline \multicolumn{13}{|l|}{ (Founder characteristics) } \\
\hline Age at start-up & 0.001 & {$[0.001]$} & & 0.004 & {$[0.002]$} & $*$ & -0.002 & {$[0.002]$} & & -0.000 & {$[0.000]$} & \\
\hline Gender (female) dummy & -0.068 & {$[0.045]$} & & 0.039 & {$[0.095]$} & & -0.398 & {$[0.095]$} & $* *$ & -0.001 & [0.014] & \\
\hline Education: University & 0.068 & {$[0.020]$} & $* *$ & 0.297 & {$[0.041]$} & ** & 0.121 & {$[0.037]$} & $* *$ & 0.028 & {$[0.007]$} & ** \\
\hline Education: Junior or technical college & 0.097 & {$[0.069]$} & & 0.025 & {$[0.151]$} & & 0.283 & {$[0.122]$} & $*$ & -0.011 & {$[0.020]$} & \\
\hline Industry experience: 3-10 years & 0.044 & {$[0.037]$} & & 0.016 & {$[0.079]$} & & 0.039 & {$[0.070]$} & & 0.005 & [0.012] & \\
\hline Industry experience: 10 or more years & 0.076 & {$[0.032]$} & $*$ & 0.085 & {$[0.068]$} & & 0.150 & {$[0.059]$} & $*$ & 0.002 & {$[0.010]$} & \\
\hline Managerial experience: 3-10 years & -0.057 & {$[0.027]$} & $*$ & -0.066 & {$[0.056]$} & & -0.398 & {$[0.053]$} & $* *$ & -0.021 & {$[0.007]$} & $*$ \\
\hline Managerial experience: 10 or more years & -0.140 & {$[0.029]$} & $* *$ & -0.199 & {$[0.061]$} & ** & -0.589 & {$[0.059]$} & $* *$ & -0.029 & [0.008] & $* *$ \\
\hline Strength in sales & 0.130 & {$[0.027]$} & $* *$ & 0.018 & {$[0.056]$} & & 0.291 & {$[0.052]$} & $* *$ & 0.023 & {$[0.008]$} & $* *$ \\
\hline Strength in technology & 0.067 & {$[0.028]$} & $*$ & 0.138 & {$[0.057]$} & $*$ & 0.054 & {$[0.052]$} & & -0.009 & [0.008] & \\
\hline Strength in accounting & 0.177 & {$[0.063]$} & $* *$ & 0.075 & {$[0.134]$} & & 0.360 & {$[0.113]$} & $* *$ & -0.013 & [0.018] & \\
\hline Strength in administration & 0.043 & {$[0.026]$} & & 0.045 & {$[0.055]$} & & 0.109 & {$[0.048]$} & $*$ & 0.015 & [0.009] & \\
\hline Personality - careful & -0.038 & {$[0.032]$} & & -0.045 & {$[0.069]$} & & -0.105 & {$[0.063]$} & & -0.013 & {$[0.010]$} & \\
\hline Personality - active & 0.057 & {$[0.022]$} & $*$ & 0.104 & {$[0.047]$} & $*$ & 0.122 & {$[0.041]$} & $* *$ & -0.005 & {$[0.007]$} & \\
\hline Personality - responsible & -0.032 & {$[0.026]$} & & -0.079 & {$[0.055]$} & & 0.084 & {$[0.048]$} & & 0.007 & [0.009] & \\
\hline Personality - technology-oriented & -0.027 & {$[0.032]$} & & 0.092 & {$[0.065]$} & & 0.161 & {$[0.062]$} & $*$ & 0.015 & {$[0.012]$} & \\
\hline Personality - steady & 0.014 & {$[0.022]$} & & -0.004 & {$[0.047]$} & & 0.006 & {$[0.042]$} & & -0.007 & {$[0.007]$} & \\
\hline Personality - visionary & 0.008 & {$[0.027]$} & & 0.038 & {$[0.055]$} & & 0.063 & {$[0.050]$} & & 0.010 & [0.009] & \\
\hline Personality - serious & 0.045 & {$[0.021]$} & $*$ & -0.121 & {$[0.043]$} & $* *$ & 0.152 & {$[0.039]$} & $* *$ & 0.013 & {$[0.007]$} & $*$ \\
\hline Personality - wide personal network & 0.054 & {$[0.025]$} & $*$ & 0.111 & {$[0.051]$} & $*$ & -0.006 & {$[0.048]$} & & 0.025 & [0.009] & ** \\
\hline Personality - person who gets things done & -0.002 & {$[0.021]$} & & -0.043 & {$[0.044]$} & & 0.075 & [0.039] & & 0.004 & {$[0.007]$} & \\
\hline Personality - sociable & 0.095 & {$[0.023]$} & $* *$ & 0.074 & {$[0.049]$} & & 0.139 & {$[0.043]$} & $* *$ & 0.001 & {$[0.008]$} & \\
\hline Personality - superior planning ability & 0.021 & {$[0.025]$} & & 0.000 & {$[0.051]$} & & 0.143 & {$[0.046]$} & $* *$ & 0.019 & {$[0.008]$} & $*$ \\
\hline Constant & 0.792 & {$[0.072]$} & $* *$ & -1.318 & [0.152] & $* *$ & -2.066 & [0.135] & $* *$ & & & \\
\hline Sample size & 4,847 & & & 4,847 & & & 6,582 & & & 6,582 & & \\
\hline Log likelihood & $-11,711$ & & & $-6,550$ & & & $-5,881$ & & & $-1,857$ & & \\
\hline R-squared & 0.022 & & & 0.044 & & & 0.072 & & & 0.130 & & \\
\hline
\end{tabular}

1) We report regression coefficients for Models 1 to 3 and marginal effects for Model 4. Standard errors are in brackets.

2) Levels of significance: $* * \mathrm{p}<0.01,{ }^{*} \mathrm{p}<0.05$. 


\section{Appendix: Correlation matrix of the variables}

\begin{tabular}{|c|c|c|c|c|c|c|c|c|c|c|c|}
\hline & Variables & [1] & [2] & [3] & [4] & [5] & [6] & [7] & [8] & [9] & [10] \\
\hline [1] & Number of customers & 1.000 & & & & & & & & & \\
\hline$[2]$ & Number of listed customers & 0.696 & 1.000 & & & & & & & & \\
\hline [3] & Number of lenders of bank loans & 0.145 & 0.063 & 1.000 & & & & & & & \\
\hline [4] & Borrowing from city bank & 0.075 & 0.054 & 0.531 & 1.000 & & & & & & \\
\hline [5] & Firm age & 0.103 & 0.063 & 0.116 & 0.188 & 1.000 & & & & & \\
\hline [6] & Number of employees & 0.135 & 0.172 & -0.033 & -0.047 & -0.003 & 1.000 & & & & \\
\hline [7] & Ianufacturing sec & -0.032 & 0.002 & -0.043 & 0.047 & -0.089 & 0.226 & 1.000 & & & \\
\hline [8] & Wholesale sector & 0.002 & -0.026 & 0.015 & 0.057 & -0.024 & -0.095 & -0.375 & 1.000 & & \\
\hline [9] & Bussiness service sector & 0.024 & 0.024 & 0.020 & -0.093 & 0.095 & -0.090 & -0.441 & -0.666 & 1.000 & \\
\hline [10] & Location - Tokyo or Osaka & 0.095 & 0.113 & 0.120 & -0.079 & 0.060 & 0.025 & -0.236 & -0.080 & 0.267 & 1.000 \\
\hline [11] & Age at start-up & 0.006 & 0.064 & -0.082 & -0.019 & -0.059 & 0.186 & 0.281 & 0.152 & -0.373 & -0.220 \\
\hline [12] & Genc & 0.008 & -0.000 & 0.001 & 0.039 & 0.008 & -0.029 & 0.027 & -0.032 & 0.009 & 0.054 \\
\hline [13] & Educ & -0.033 & 0.023 & 0.044 & -0.085 & -0.024 & 0.025 & 0.008 & 0.025 & -0.030 & 0.079 \\
\hline [14] & Indus & 0.045 & -0.038 & 0.017 & 0.009 & 0.033 & -0.068 & -0.089 & -0.101 & 0.169 & 0.087 \\
\hline [15] & Industry ex & 0.037 & 0.073 & -0.018 & 0.016 & -0.007 & 0.079 & 0.077 & 0.102 & -0.161 & -0.061 \\
\hline [16] & Managerial e & 0.108 & 0.163 & -0.008 & -0.013 & 0.038 & 0.166 & -0.019 & 0.008 & 0.007 & 0.047 \\
\hline [17] & Managerial es & -0.038 & -0.024 & -0.044 & -0.013 & 0.000 & 0.026 & 0.168 & 0.050 & -0.183 & -0.137 \\
\hline [18] & Strength in sa & 0.058 & 0.003 & 0.061 & 0.070 & 0.047 & -0.042 & -0.180 & 0.245 & -0.093 & 0.032 \\
\hline [19] & Stren & -0.015 & 0.038 & 0.009 & -0.053 & 0.018 & -0.049 & 0.015 & -0.242 & 0.222 & 0.109 \\
\hline [20] & Stre & -0.002 & -0.020 & -0.049 & 0.013 & -0.012 & -0.003 & 0.100 & -0.028 & -0.053 & 0.017 \\
\hline [21] & tration & 0.009 & 0.003 & -0.056 & -0.027 & -0.017 & 0.072 & 0.158 & -0.036 & -0.092 & -0.094 \\
\hline [22] & Perso & -0.016 & 0.019 & -0.055 & -0.063 & 0.011 & 0.086 & 0.122 & -0.030 & -0.069 & -0.099 \\
\hline [23] & Personality - active & 0.077 & 0.083 & 0.021 & 0.029 & 0.054 & 0.051 & -0.058 & 0.056 & -0.007 & 0.049 \\
\hline [24] & Personality - $\mathrm{r}$ & -0.060 & -0.040 & 0.002 & 0.009 & 0.031 & 0.071 & 0.111 & 0.011 & -0.100 & 0.027 \\
\hline [25] & Perso & -0.057 & 0.004 & 0.002 & 0.008 & 0.045 & -0.049 & 0.073 & -0.147 & 0.084 & 0.041 \\
\hline [26] & Perso & 0.008 & 0.009 & 0.047 & 0.082 & -0.039 & 0.099 & 0.058 & 0.109 & -0.152 & -0.072 \\
\hline [27] & Personality - & -0.001 & -0.035 & 0.003 & -0.008 & 0.019 & 0.004 & -0.008 & -0.081 & 0.084 & 0.049 \\
\hline [28] & Personality - serious & -0.026 & -0.058 & -0.015 & 0.035 & 0.012 & -0.008 & 0.060 & 0.050 & -0.097 & -0.127 \\
\hline [29] & Personality - wide personal network & 0.023 & 0.075 & 0.079 & 0.022 & -0.015 & -0.032 & -0.057 & 0.019 & 0.027 & 0.069 \\
\hline [30] & Personality - person who gets things done & 0.037 & -0.013 & 0.036 & 0.010 & 0.065 & -0.007 & -0.091 & 0.038 & 0.037 & 0.139 \\
\hline [31] & Personality - sociable & -0.031 & -0.033 & 0.003 & 0.005 & -0.032 & -0.030 & -0.062 & 0.091 & -0.038 & -0.038 \\
\hline [32] & Personality - superior planning ability & 0.029 & -0.018 & -0.019 & -0.072 & 0.027 & -0.042 & -0.083 & -0.154 & 0.216 & 0.265 \\
\hline
\end{tabular}




\section{Appendix: Correlation matrix of the variables (cont.)}

\begin{tabular}{|c|c|c|c|c|c|c|c|c|c|c|c|c|}
\hline & Variables & [11] & [12] & [13] & [14] & [15] & {$[16]$} & [17] & [18] & [19] & {$[20]$} & [21] \\
\hline [11] & Age at start-up & 1.000 & & & & & & & & & & \\
\hline [12] & Gender (female) dummy & -0.045 & 1.000 & & & & & & & & & \\
\hline [13] & Education: University & 0.039 & -0.152 & 1.000 & & & & & & & & \\
\hline [14] & Industry experience: 3-10 years & -0.416 & 0.018 & -0.024 & 1.000 & & & & & & & \\
\hline [15] & Industry experience: 10 or more years & 0.441 & -0.083 & 0.041 & -0.763 & 1.000 & & & & & & \\
\hline [16] & Managerial experience: 3-10 years & 0.023 & -0.004 & 0.028 & 0.006 & 0.030 & 1.000 & & & & & \\
\hline [17] & Managerial experience: 10 or more years & 0.396 & 0.040 & -0.033 & -0.182 & 0.201 & -0.231 & 1.000 & & & & \\
\hline [18] & Strength in sales & -0.077 & -0.097 & 0.027 & 0.010 & 0.011 & -0.061 & -0.036 & 1.000 & & & \\
\hline [19] & Strength in technology & -0.072 & -0.016 & -0.027 & -0.023 & 0.078 & -0.019 & -0.054 & -0.460 & 1.000 & & \\
\hline [20] & Strength in accounting & -0.032 & 0.106 & -0.043 & 0.013 & -0.111 & 0.060 & -0.044 & -0.153 & -0.078 & 1.000 & \\
\hline [21] & Strength in administration & 0.138 & 0.059 & 0.057 & -0.036 & -0.016 & 0.108 & 0.142 & -0.303 & -0.222 & 0.074 & 1.000 \\
\hline [22] & Personality - careful & 0.104 & -0.018 & 0.015 & -0.007 & 0.007 & -0.014 & 0.009 & -0.041 & 0.017 & -0.004 & 0.049 \\
\hline [23] & Personality - active & -0.035 & 0.017 & -0.025 & 0.032 & -0.001 & 0.052 & 0.081 & 0.158 & -0.116 & -0.036 & -0.037 \\
\hline [24] & Personality - responsible & 0.037 & -0.033 & -0.026 & -0.111 & 0.062 & 0.042 & 0.023 & -0.025 & -0.024 & 0.076 & 0.102 \\
\hline [25] & Personality - technology-oriented & 0.008 & 0.028 & 0.015 & -0.002 & 0.049 & -0.077 & -0.038 & -0.289 & 0.437 & -0.022 & -0.142 \\
\hline [26] & Personality - steady & 0.109 & -0.045 & 0.038 & -0.074 & 0.070 & -0.041 & -0.011 & -0.032 & -0.036 & 0.016 & 0.064 \\
\hline [27] & Personality - visionary & -0.093 & -0.007 & 0.016 & 0.068 & -0.039 & 0.022 & -0.052 & 0.089 & 0.047 & 0.042 & -0.025 \\
\hline [28] & Personality - serious & 0.049 & -0.042 & 0.042 & -0.020 & 0.005 & -0.013 & -0.044 & -0.122 & 0.056 & 0.032 & 0.092 \\
\hline [29] & Personality - wide personal network & 0.028 & -0.032 & -0.016 & 0.019 & -0.002 & 0.010 & -0.002 & 0.119 & -0.041 & -0.049 & 0.005 \\
\hline [30] & Personality - person who gets things done & -0.100 & -0.016 & -0.015 & -0.027 & 0.018 & 0.049 & 0.081 & 0.132 & -0.064 & -0.013 & -0.005 \\
\hline [31] & Personality - sociable & -0.003 & 0.032 & -0.052 & 0.012 & 0.014 & -0.024 & -0.034 & 0.127 & -0.076 & -0.048 & -0.026 \\
\hline [32] & Personality - superior planning ability & -0.181 & 0.082 & 0.021 & 0.045 & -0.065 & 0.026 & -0.027 & 0.036 & 0.061 & 0.015 & 0.001 \\
\hline & Variables & {$[22]$} & {$[23]$} & {$[24]$} & [25] & {$[26]$} & {$[27]$} & {$[28]$} & [29] & {$[30]$} & {$[31]$} & {$[32]$} \\
\hline$\overline{[22]}$ & Personality - careful & 1.000 & & & & & & & & & & \\
\hline [23] & Personality - active & -0.131 & 1.000 & & & & & & & & & \\
\hline [24] & Personality - responsible & 0.021 & -0.044 & 1.000 & & & & & & & & \\
\hline [25] & Personality - technology-oriented & 0.076 & -0.132 & -0.071 & 1.000 & & & & & & & \\
\hline [26] & Personality - steady & 0.052 & -0.211 & 0.008 & -0.020 & 1.000 & & & & & & \\
\hline [27] & Personality - visionary & -0.086 & -0.016 & -0.018 & 0.022 & -0.107 & 1.000 & & & & & \\
\hline [28] & Personality - serious & 0.141 & -0.289 & 0.084 & 0.084 & 0.211 & -0.171 & 1.000 & & & & \\
\hline [29] & Personality - wide personal network & -0.102 & 0.058 & -0.081 & -0.058 & -0.082 & 0.040 & -0.171 & 1.000 & & & \\
\hline [30] & Personality - person who gets things done & -0.129 & 0.115 & -0.048 & -0.071 & -0.131 & 0.040 & -0.188 & 0.051 & 1.000 & & \\
\hline [31] & Personality - sociable & -0.043 & 0.046 & -0.091 & -0.075 & -0.044 & -0.016 & -0.105 & 0.003 & -0.030 & 1.000 & \\
\hline [32] & Personality - superior planning ability & -0.123 & 0.010 & -0.016 & -0.046 & -0.193 & 0.154 & -0.225 & 0.027 & 0.181 & -0.033 & 1.000 \\
\hline
\end{tabular}

